\title{
PEMAHAMAN KONSEP SEGIEMPAT SISWA DITINJAU DARI TIPE KEPRIBADIAN EKSTROVERT-INTROVERT DAN JENIS KELAMIN
}

\author{
Rista Amelia \\ Program Studi Pendidikan Matematika, Jurusan Matematika, FMIPA, Universitas Negeri Surabaya \\ e-mail: ristaamelia16030174002@mhs.unesa.ac.id \\ Ismail \\ Program Studi Pendidikan Matematika, Jurusan Matematika, FMIPA, Universitas Negeri Surabaya \\ $e$-mail: ismail@unesa.ac.id
}

\begin{abstract}
Abstrak
Pemahaman konsep merupakan salah satu faktor penting dalam tujuan pembelajaran matematika. Pemahaman konsep merupakan kemampuan siswa dalam penguasaan suatu konsep baik dalam menjelaskan maupun mengamplikasikan suatu konsep dalam suatu pemecahan soal maupun pemecahan masalah. Kepribadian berperan dalam proses belajar siswa hal ini dikarenakan sikap setiap individu dalam mengambil keputusan dipengaruhi oleh kebiasaan. Kepribadian dan perbedaan jenis kelamin dapat memungkinkan adanya perbedaan pemahaman konsep. Penelitian ini merupakan penelitian deskripstif kualitatif dengan tujuan untuk mendeskripsikan pemahaman konsep segiempat siswa ditinjau dari tipe kepribadian ekstrovertintrovert dan jenis kelamin. Pada penelitian ini empat siswa SMP dipilih sebagai subjek yang ditentukan berdasarkan tipe kepribadian ekstrovert-introvert dan jenis kelamin. Instrument pengumpulan data yang digunakan terdiri dari tes kemampuan matematika, angket kepribadian MBTI, tes pemahaman konsep materi segiempat dan pedoman wawancara. Hasil penelitian ini menunjukan (a) Siswa laki-laki ekstrovert kurang mampu menyatakan ulang konsep segiempat, dan kurang mampu menggunakan dan memanfaatkan serta memilih prosedur atau operasi untuk menyelesaikan soal segiempat (b) Siswa perempuan ekstrovert kurang mampu menyatakan ulang konsep segiempat, kurang mampu mengkalsifikasikan segiempat berdasarkan sifat-sifat yang sesuai, dan kurang mampu menggunakan dan memanfaatkan serta memilih prosedur atau operasi untuk menyelesaikan soal segiempat (c) Siswa laki-laki introvert kurang mampu menyatakan ulang konsep segiempat, kurang mampu mengkalsifikasikan segiempat berdasarkan sifat-sifat yang sesuai, (d) Siswa perempuan introvert kurang mampu mengkalsifikasikan segiempat berdasarkan sifat-sifat yang sesuai. Implikasi hasil penelitian ini adalah pemahaman konsep pada tiap kepribadian baik laki-laki maupun perempuan perlu diperhatikan.
\end{abstract}

Kata Kunci: Pemahaman konsep, segiempat, ekstrovert-introvert dan jenis kelamin.

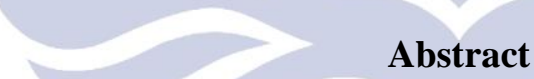

Understanding the concept is one important factor in the purpose of learning mathematics. Understanding concepts is the ability of students in mastering a concept both in explaining and applying a concept in problem solving or problem solving. Personality plays a role in the learning process of students this is because the attitude of each individual in making decisions is influenced by habits. Personality and gender differences can allow differences in understanding of concepts. This research is a qualitative descriptive study with the aim to describe the understanding of the quadrilateral concept of students in terms of extrovert-introvert personality types and gender. In this study four junior high school students were chosen as subjects determined by extrovert-introvert personality types and gender. Data collection instruments used consisted of mathematics ability tests, MBTI personality questionnaires, quadrilateral understanding of concept material tests and interview guidelines. The results of this study indicate (a) Extroverted male students are less able to restate the quadrilateral concept, and less able to use and utilize and choose procedures or operations to solve quadrilateral problems (b) Extroverted female students are less able to restate the quadrilateral concept, less able to calcify quadrilateral based on appropriate traits, and less able to use and utilize and choose procedures or operations to solve quadrilateral problems (c) Introverted male students are less able to restate the quadrilateral concept, less able to calcify rectangles based on appropriate traits, (d) Introverted female students are less able to calcify quadrilateral based on appropriate traits. The implication of the results of this study is the understanding of the concepts in each personality of both men and women need to be considered.

Keywords: Understanding of concepts, quadrilateral, ekstrovert-introvert and gender. 


\section{PENDAHULUAN}

Matematika merupakan ilmu pengetahuan yang mendasari ilmu pengetahuan lainnya. Hal ini dapat dibuktikan dengan implementasi matematika pada setiap jenjang pendidikan mulai dari sekolah dasar hingga jenjang perguruan tinggi. Sependapat dengan hal itu menurut Cockroft (dalam Hamzah dan Masri, 2009) matematika perlu dipelajari. Hal ini dikarenakan dalam kehidupan sehari-hari misalnya bagi perdagangan, ilmu pengetahuan, selain itu matematika dapat menjadi alat komukasi yang singkat serta dapat berfungsi sebagai alat untuk memprediksi dan mendeskripsikan suatu hal. Hal itu menunjukan mengapa matematika telah diperkenalkan mulai dari usia dini.

Akan tetapi banyak siswa cenderung kurang dalam kemampuan pemecahan masalah, hal tersebut dikarenakan hingga saat ini siswa menganggap matematika sebagai mata pelajaran yang tidak menyenangkan dan sulit dipahami. Kondisi tersebut berdampak dan mengakibatkan banyak siswa kurang mampu memahami konsep-konsep matematika dengan baik yang berpengaruh dalam hasil berlajar siswa sehingga mengakibatkan siswa memperoleh hasil belajar matematika yang kurang memuaskan. Siswa dapat dikatakan berhasil dalam pembelajaran matematika salah satunya apabila siswa memiliki penguasaan konsep yang baik.

Menurut Sagala (dalam Fatqurhohman, 2016), konsep merupakan suatu ide abstraksi yang mewakili objek-objek, kejadian-kejadian, kegiatan-kegiatan, atau hubunganhubungan yang mempunyai atribut-atribut yang sama. Hal ini dikarenakan terdapat keterkaitan yang kuat antar satu konsep dengan konsep lainnya pada setiap konsep matematika. Dalam proses pembelajaran matematika, pemahaman konsep merupakan landasan yang sangat penting. Menurut Wardhani (2008), pemahaman konsep adalah menjelaskan keterkaitan antara konsep dan mengaplikasikan konsep atau logaritma, secara luwes, dan tepat dalam pemecahan masalah.

Menurut Depdiknas (Permendiknas no 22 tahun 2006) pentingnya pemahaman konsep menjadi tujuan pertama pembelajaran matematika kemudian dilanjutkan menjelaskan keterkaitan antar konsep dan mengaplikasikan konsep atau algoritma secara luwes, akurat, efisien dan tepat dalam pemecahan masalah. Hal ini sejalan dengan Zulkardi (2003:7) yang mengatakan bahwa konsep sangat ditekankan dalam mata pelajaran matematika. Artinya jika ingin dapat menyelesaikan soalsoal serta jika ingin mengaplikasikan pembelajaran tersebut kedalam dunia nyata maka siswa harus memahami konsep matematika terlebih dahulu.

Salah satu konsep matematika yang diajarkan pada jenjang SMP yaitu konsep-konsep geometri. Tetapi materi pokok geometri merupakan salah satu materi matematika yang sulit dipahami oleh siswa karena keabstrakannya. Hal ini didukung oleh Sunardi (2008) yang menyatakan bahwa hasil pembelajaran masih belum memuaskan dikarenakan banyak siswa yang mengalami kesulitan sehingga belum memahami konsep-konsep geometri diantaranya konsep segiempat. Diketahui bahwa materi segiempat sangat penting dipelajari karena materi segiempat merupakan dasar dalam mempelajari materi geometri berikutnya seperti bangun ruang. Oleh karena itu siswa diharuskan paham akan konsep segiempat agar tidak mengalami kesulitan dalam mempelajari materi selanjutnya seperti bangun ruang pada pembelajaran matematika berikutnya.

Dalam memahami suatu konsep siswa mempunyai cara yang berbeda-beda. Salah satu faktor yang menyebabkan perbedaan itu adalah kepribadian. Sejalan dengan itu Kiswanto (2015) mengatakan bahwa seseorang memiliki perbedaan pemahaman dan presepsi terhadap informasi yang sama, hal tersebut bergantung pada fokus perhatiannya pada suatu informasi dan kemampuan dalam memfokuskan informasi yang diterimanya terkait dengan kepribadian yang dimiliki.

Kepribadian adalah keseluruhan pola sikap, ekspresi, perasaan serta kebiasaan seseorang dalam menghadapi situasi. Pangarso (2012) mengatakan bahwa kebiasaan akan mempengaruhi sikap seseorang serta mempengaruhi seseorang dalam mengambil keputusan dalam bertindak. Jung (2016) mengelompokan tipe kepribadian menjadi dua kelompok besar yaitu extrovert dan introvert. Berdasarkan pada hal tersebut jika dikaitkan maka pemahaman konsep memiliki keterkaitan dengan kepribadian dikarenakan kepribadian memiliki peran dalam pemahaman dan kegiatan pengambilan keputusan dalam pembelajaran matematika. Hal tersebut sejalan dengan Qomariah (2016) yang menyatakan bahwa kepribadian ekstrovert-introvert turut berperan penting dalam memahami suatu konsep pada kegiatan proses pembelajaran.

Selain kepribadian yang dimiliki tiap individu, baik laki-laki maupun perempuan terdapat perbedaan, hal ini didukung oleh beberapa teori, misalnya Kartono (2006) menyatakan bahwa pada umumnya perempuan lebih akurat dan lebih mendetail dalam memperhatikan sesuatu dibandingkan laki-laki. Noureen \& Sheikh (2016) mengatakan bahwa penelitian yang telah dilakukan di Australia, Inggris, Hongkong, dan masih banyak lagi pada umumnya menunjukan bahwa kemampuan perempuan lebih baik dari pada laki-laki pada bidang matematika pada tiap jenjang. Nuryoto (1998) dalam penelitiannya yang dilakukan pada siswa SD, SMP, SMA menyatakan bahwa secara umum prestasi akademik perempuan lebih baik dibandingkan dengan laki-laki. 
Akan tetapi, New South Wales Department of Education (dalam Lestari, 2010:36) mengatakan bahwa siswa perempuan mempunyai harapan yang lebih rendah untuk berprestasi dalam bidang matematika dibandingkan dengan siswa laki-laki, dan dalam penelitian tersebut juga dijelaskan bahwa siswa perempuan selalu menolak dalam mengambil resiko dalam pemecahan masalah. Sependapat dengan itu OECD (2014) mengatakan bahwa siswa lakilaki lebih memilki rasa ingin tahu dan ketertarikan yang besar terhadap masalah dan lebih bervariatif dalam melakukan suatu penyelesaian dibandingkan dengan siswa perempuan jika dilihat dari prestasi belajar yang dihubungkan dengan pemecahan masalah dan dikaitkan dengan jenis kelamin. Oleh karena itu, Lutfiyah, dkk (2018) mengatakan bahwa jenis kelamin telah berkembang menjadi perbedaan kemampuan antara lakilaki dan perempuan dan tidak lagi hanya berkaitan dengan faktor biologi saja.

Berdasarkan uraian-uraian di atas, maka peneliti ingin mengetahui bagaimana pemahaman siswa terhadap konsep segiempat ditinjau dari tipe kepribadian extrovertintrovert dan jenis kelamin. Adapun indikator pemahaman konsep segiempat pada penelitian ini sebagai berikut: (1) Menyatakan ulang konsep segiempat, Mengklasifikasikan segiempat berdasarkan sifat-sifat yang sesuai, (3) Memberikan contoh dan non-contoh dari segiempat, (4) Menyajikan konsep segiempat ke dalam berbagai bentuk representasi matematika, (5) Menggunakan dan memanfaatkan serta memilih prosedur atau operasi untuk menyelesaikan soal segiempat

\section{METODE}

Penelitian ini merupakan penelitian deskriptif kualitatif yang bertujuan mendeskripsikan pemahaman konsep segiempat siswa SMP ditinjau dari tipe kepribadian ekstrover-introvert dan jenis kelamin

Subjek pada penelitian ini terdiri dari 4 siswa kelas VIII SMP tahun ajaran 2019/2020 dengan rincian 1 siswa laki-laki ekstrovert, 1 siswa laki-laki introvert, 1 siswa perempuan ekstrovert, dan 1 siswa perempuan introvert dengan kemampuan matematika yang setara, selisih skor maksimal 5 poin pada tes kemampuan matematika, dan komunikatif. Instrumen yang digunakan pada penelitian ini yaitu angket tipe kepribadian ekstrovert-introvert, tes kemampuan matematika, tes pemahaman konsep segiempat, dan pedoman wawancara. Angket tipe kepribadian dalam penelitian ini menggunakan tes kepribadian Myers-Briggs Type Indicator (MBTI) untuk mengetahui kepribadian yang dimiliki siswa dalam dimensi ekstrovert-introvert. Selanjutnya, untuk mendapatkan data nilai matematika siswa kelas VIII menggunakan tes kemampuan matematika. Tes pemahaman konsep segiempat bertujuan untuk mendapatkan data pemahaman konsep pada subjek yang telah ditentukan, tes ini disusun dengan memperhatikan indikator pemahaman konsep segiempat

Pemilihan subjek berdasarkan hasil analisis data angket tipe kepribadian dan tes kemampuan matematika. Subjek yang tepilih akan mengerjakan Tes Pemahaman Konsep Segiempat kemudian dilanjutkan dengan Wawancara. Selanjutnya hasil dari analisis dari Tes Pemahaman Konsep Segiempat dan Wawancara akan dideskripsikan untuk melihat pemahaman konsep segiempat siswa SMP berdasarkan tipe kepribadian dan jenis kelamin.

Pengambilan data dilakukan pada 25 Februari sampai 3 Maret 2020 dikelas VIII-H SMP Negeri 13 Surabaya

\section{HASIL DAN PEMBAHASAN}

Hasil dan pembahasan mengenai pemahaman konsep segiempat siswa SMP baik laki-laki maupaun perempuan berkepribadian ektrovert maupun introvert diperoleh berdasarkan analisis data yang dilakukan. Berikut rincian hasil dan pembahasan pada penelitian ini:

1. Hasil Penelitian

a. Subjek Laki-Laki Berkepribadian Ekstrovert (SLE)

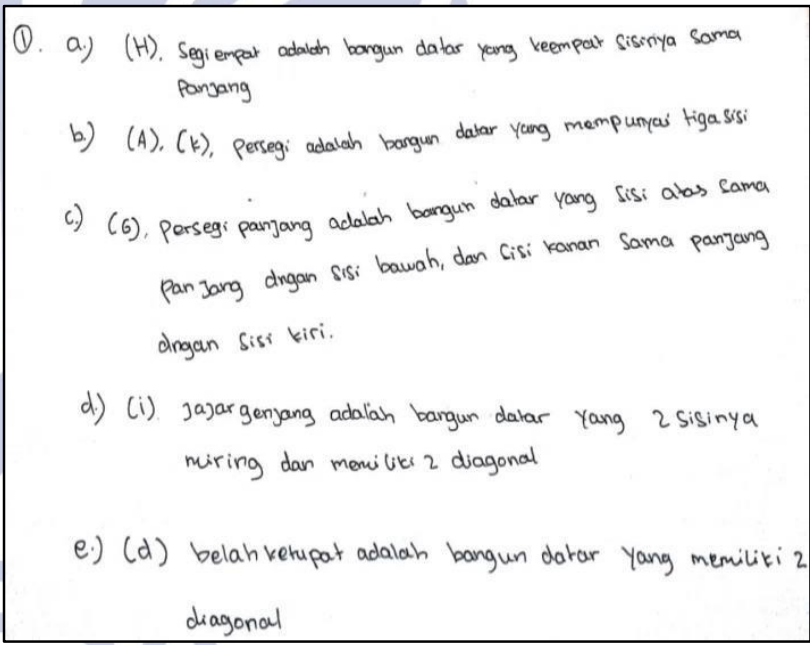

Gambar 1. SLE dalam Menyatakan Ulang Konsep Segiempat

Gambar 1 menunjukan bahwa SLE dalam menyatakan ulang konsep segiempat dengan menggolongkan tiap bangun yang termasuk segiempat masih kurang, hal ini terlihat SLE hanya memilih satu bangun yang termasuk segiempat. Lebih lanjut SLE melakukan kekeliruan dalam memilih bangun datar yang termasuk persegi, hal ini dikarenakan SLE keliru menganggap segitiga sebagai persegi. 


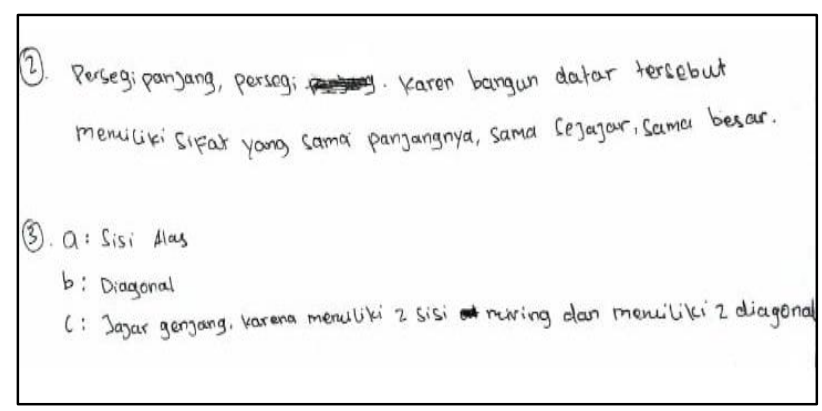

Gambar 2. SLE dalam Mengkalsifikasikan Segiempat Berdasarkan Sifat-Sifat Yang Sesuai

Gambar 2 menunjukan SLE mampu mengklasifikasikan segiempat berdasarkan sifat-sifat yang sesuai. Hal ini telihat SLE mampu menjawab bangun segiempat apa yang dimaksud berdasarkan sifat-sifat yang tertera. Selanjutnya SLE dapat menyebutkan suatu bangun berdasarkan gambar dengan benar serta menyebutkan bagian-bagian yang dimaksud dengan benar serta penjelasan dari SPE jelas.

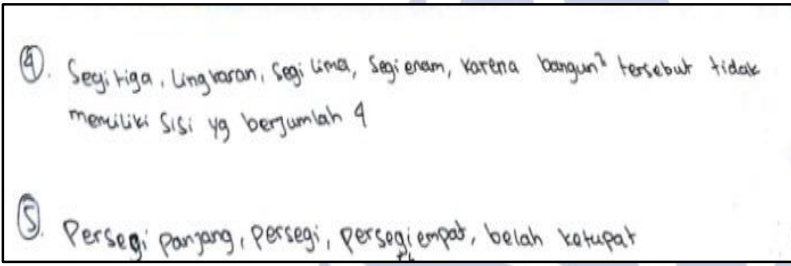

Gambar 3. SLE dalam Memberikan Contoh dan NonContoh Dari Segiempat

Gambar 3 menunjukan SLE mampu memberikan noncontoh dari segiempat dengan benar beserta penjelasan dengan jelas. Namun pada memberikan contoh dari segiempat terdapat jawaban yang kurang jelas. Tetapi saat wawancara, SLE terlihat mampu memberikan contoh dari segiempat dengan tepat [SLE5020]. Berikut transkrip wawancara SLE dalam memberikan contoh dan noncontoh dari segiempat

\begin{tabular}{|c|c|l||}
\hline P4017 & $:$ & $\begin{array}{l}\text { Coba kamu sebutkan bangun datar yang } \\
\text { bukan termasuk segiempat dan apa alasanya? }\end{array}$ \\
\hline SLE4017 & $:$ & $\begin{array}{l}\text { Segitiga, lingkaran, segienam kak. Karena } \\
\text { sisi yang dimiliki bangun-angun tersebut } \\
\text { tidak berjumlah 4 }\end{array}$ \\
\hline P5018 & $:$ & $\begin{array}{l}\text { Selanjutnya coba kamu sebutkan empat } \\
\text { contoh segiempat. }\end{array}$ \\
\hline SLE5018 & $:$ & $\begin{array}{l}\text { Persegipanjang, persegi, persegiempat, } \\
\text { belahketupat }\end{array}$ \\
\hline P5019 & $:$ & Maksudnya persegiempat ini apa? \\
\hline SLE5019 & $:$ & Yang memiliki 4 sisi kak \\
\hline P5020 & $:$ & $\begin{array}{l}\text { Iya dek tapi ini soalnyakan sebutkan contoh } \\
\text { dari segiempat, coba sebutkan lagi contoh } \\
\text { yang lain! }\end{array}$ \\
\hline SLE5020 & $:$ & $\begin{array}{l}\text { Layang-layang kak, jadinya persegipanjang, } \\
\text { persegi, belahketupat dan layang-lanyang }\end{array}$ \\
\hline
\end{tabular}

Gambar 4. Transkrip wawancara SLE dalam memberikan contoh dan non-contoh dari segiempat

Gambar 4 menunjukan SLE mampu memberikan noncontoh dengan tepat serta memberikan alsan dengan jelas dan juga mampu memberikan contoh dari segiempat dengan tepat.

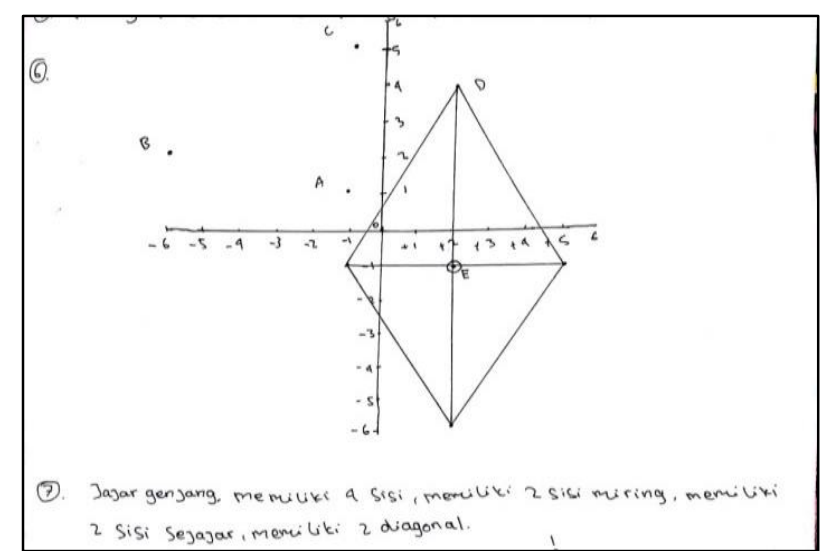

Gambar 5. SLE Menyajikan Konsep Segiempat dalam

Berbagai Bentuk Repsresentasi Matematika

Gambar 5 menunjukan SLE mampu menyajikan konsep segiempat ke dalam berbagai bentuk repsresentasi matematika. Hal ini dikarenakan SLE mampu mengubah informasi verbal ke dalam bentuk visual, hanya saja SLE belum menuliskan bangun apa yang terbentuk, SLE mampu menentukan dimana titik E berada dengan tepat dan mampu menyebutkan bangun yang terbentuk. Selanjutnya subjek SLE juga mampu mengubah informasi visual ke dalam bentuk verbal dengan benar, hanya saja jawaban tertulis dari SLE belum rinci. Tetapi saat wawancara, SLE mampu menjelaskan dengan tepat. Berikut transkrip wawancara SLE dalam menyajikan konsep segiempat ke dalam berbagai bentuk respresentasi matematika.

\begin{tabular}{|l|c|l|}
\hline P6021 & $:$ & $\begin{array}{l}\text { Coba kamu jelaskan cara kamu menyelesaikan } \\
\text { soal ini dan kamu sebutkan bangun apa yang } \\
\text { terbentuk? }\end{array}$ \\
\hline SLE6021 & $:$ & $\begin{array}{l}\text { Awalnya saya membuat sumbu koordinat } \\
\text { terlebih dahulu dan menepatkan titik-titik yang } \\
\text { diketahui dan terbentuk belahketupat kak }\end{array}$ \\
\hline P6022 & $:$ & Bagaimana dengan koordinat titik E? \\
\hline SLE6022 & $:$ & $\begin{array}{l}\text { Karena titik E itu titik potong kedua diagonal; } \\
\text { dari belah ketupat jadinya koordinat titik E itu } \\
\text { terletak di (2,-1) }\end{array}$ \\
\hline P7023 & $:$ & $\begin{array}{l}\text { Pada soal apa saja yang kamu dapatkan } \\
\text { berdasarkan infromasi yang ada? }\end{array}$ \\
\hline PLE7023 & $:$ & $\begin{array}{l}\text { Telihat dari gambar ini merupakan } \\
\text { jajargenjang, memiliki 4 sisi, memiliki 2 sisi } \\
\text { miring, 2 sisi sejajar, dan memiliki 2 diagonal }\end{array}$ \\
\hline SLE7024 & $:$ & $\begin{array}{l}\text { Kalau melihat dari jawabanmu, di sini tertulis } \\
\text { sisi sejajar, coba jelaskan maksudnya! } \\
\text { Apakah ada informasi lagi yang dapat kamu } \\
\text { jabarkan? }\end{array}$ \\
\hline
\end{tabular}

Gambar 6. Transkrips wawancara SLE dalam menyajikan konsep segiempat ke dalam berbagai bentuk representasi matematika

Gambar 6 menunjukan SLE mampu menyebutkan bangun yang terbentuk dan menjelaskan pengerjaan dengan jelas serta mampu menyebutkan letak titik $\mathrm{E}$ dengan benar, selain itu SLE mampu menjabarkan informasi secara verbal dengan jelas dan benar, oleh 
karena itu SLE mampu menyajikan konsep segiempat ke dalam berbagai bentuk representasi matematika dengan baik.

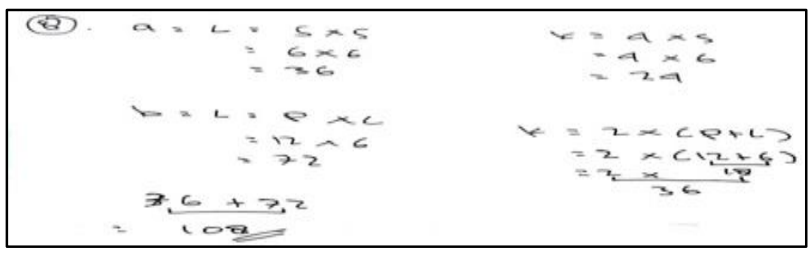

Gambar 7. SLE dalam Menggunakan dan Memanfaatkan Serta Memilih Prosedur atau Operasi Untuk Menyelesaikan Soal Segiempat

Gambar 7 menunjukan SLE belum mampu menggunakan dan memanfaatkan serta memilih prosedur atau operasi untuk menyelesaikan soal segiempat. Untuk mencari luas dari bangun tersebut SLE sudah benar dengan membagi menjadi dua bangun, hanya saja ketika mencari keliling dari bangun SLE terkecoh oleh bangun yang dibuat menjadi dua bagian untuk mencari luas bangun, sehingga SLE salah menghitung keliling bangun tersebut dengan menjumlahkan dari keliling dua bangun yang dibuat sebelumnya.

\section{b. Subjek Perempuan Berkepribadian Ektrovert (SPE)}

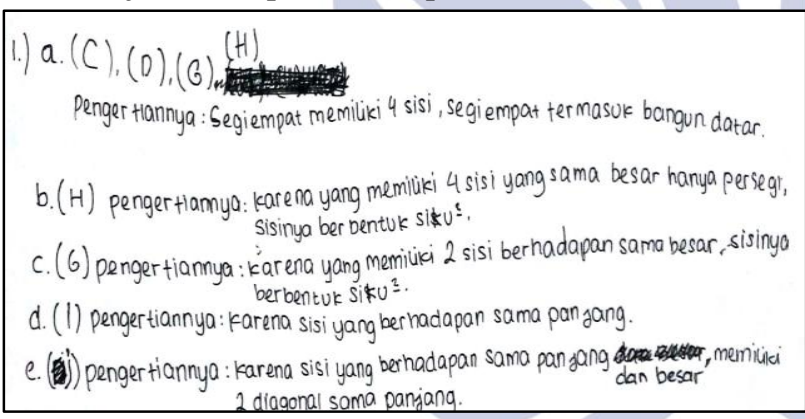

Gambar 8. Subjek SPE dalam Menyatakan Ulang Konsep Segiempat

Gambar 8 menunjukan SPE belum mampu menyatakan ulang konsep segiempat. Hal tersebut dikarenakan SPE kurang teliti sehingga dalam memilih bangun yang termasuk belahketupat SPE melakukan kesalahan dengan mengganggap layang-lanyang sebagai belahketupat, selain itu SPE dalam menjelaskan macam segiempat SPE salah dalam menganggap sudut sebagai sisi.

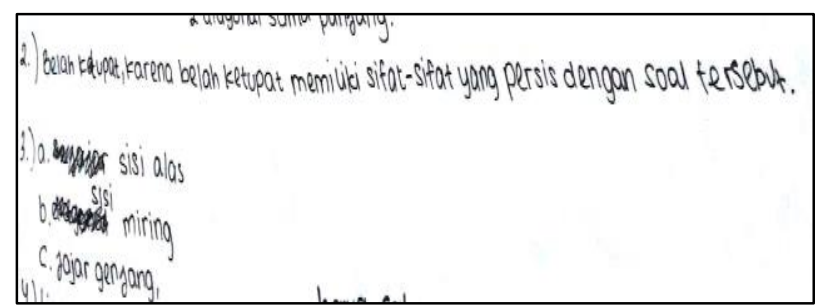

Gambar 9. SPE dalam Mengklasifikasikan Segiempat

Berdasarkan Sifat-Sifat Yang Sesuai

Gambar 9 menunjukan SPE masih kurang dalam mengklasifikasikan segiempat berdasarkan sifat-sifat yang sesuai. Hal ini dikarenakan SPE salah dalam menjawab, SPE kurang teliti dalam membaca informasi pada soal sehingga menganggap bahwa sifat-sifat yang tertera sesuai dengan sifat-sifat yang dimiliki belah ketupat. Namun pada soal selanjutnya SPE mampu menyebutkan bagianbagian yang ditanyakan dengan tepat dan menyebutkan suatu bangun berdasarkan gambar dengan benar serta memberikan penjelasan yang baik hanya saja subjek SPI tidak menulisakan penjelasan pada lembar jawaban. Dapat dikatakatan SPE kurang mampu mengklasifikasikan segiempat bersadarkan sifat-sifat yang sesuai dengan baik. 4.) lingkaran, karena lingkaran sisinya hanya satu

5.) persegi, persegi panjang, trapesium, belah ketu pat.

Gambar 10. SPE dalam Memberikan Contoh dan Non-

$$
\text { Contoh Dari Segiempat }
$$

Gambar 10 menunjukan SPE sudah memenuhi indikator memberikan contoh dan non-contoh. Hal ini dikarenakan SPE dapat menyebutkan contoh dari segiempat dengan benar dan juga dapat menyebutnya noncontoh dari segiempat dengan menyertakan alasan dengan tepat.

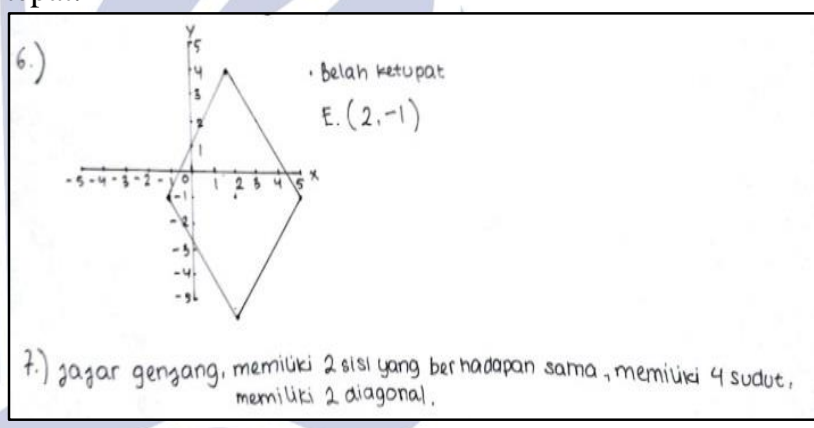

Gambar 11. SPE dalam Menyajikan Konsep Segiempat Dalam Berbagai Bentuk Repsresentasi Matematika

Gambar 11 menunjukan SPE mampu menyajikan konsep segiempat dalam berbagai bentuk representasi matematika. Hal ini terlihat subjek SPE mampu mengubah informasi verbal ke dalam bentuk visual pada sumbu koordinat dengan benar dan subjek SPE dapat menyebutkan bangun apa yang terbentuk serta dapat menentukan bahwa titik E terletak di koordinat $(2,-1)$. Selanjutnya diperkuat dengan soal selanjutnya bahwa subjek SPE dapat mengubah informasi visual kedalam bentuk verbal dengan baik.

8. Luas $I=5 \times s=6 \times 6=36$

Luas II $=p \times l=12 \times 6=72$ 108

Keliling $I=s+s+s+s=6+6+6+6=72$

kelicing $I=2 \times(P+\ell)=2 \times(12+6)=\frac{36}{108}+$

Gambar 12. SPE dalam Menggunakan Dan

Memanfaatkan Serta Memilih Prosedur Atau Operasi Untuk Menyelesaikan Soal Segiempat 
Gambar 11 menunjukan SPE kurang mampu menggunakan dan memanfaatkan serta memilih prosedur atau operasi untuk menyelesaikan soal segiempat. Pada awalnya SPE sudah memilih strategi tepat untuk menghitung atau mencari luas dari bangun tersebut dengan membagi bangun menjadi 2 bangun akan tetapi dalam menentukan keliling dari bangun SPE melakukan kesalahan, hal ini dikarenakan SPE terkecoh dengan 2 bangun yang dibuat untuk menentukan luas dan mengira bahwa keliling dari 2 bangun yang telah di buat akan sama dengan keliling bangun pada soal bahkan dalam mencari keliling SPE salah dalam melakukan perhitungan.

\section{c. Subjek Laki-Laki Berkepribadian Introvert (SLI)}

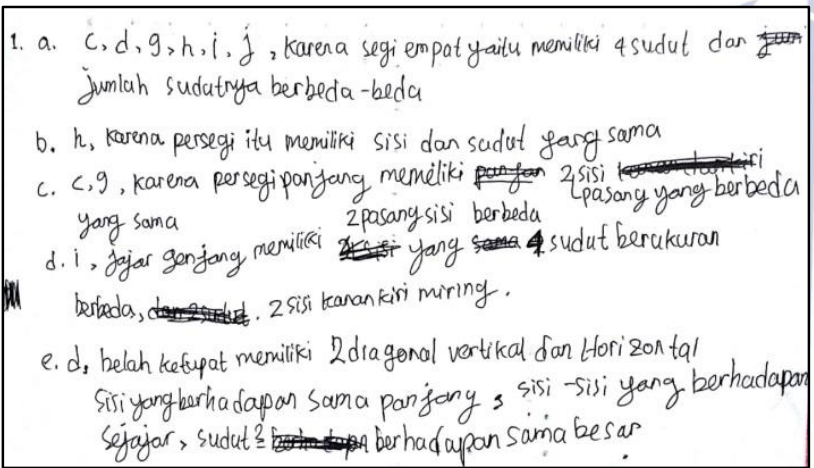

Gambar 13. SLI dalam Menyatakan Ulang Konsep Segiempat

Gambar 12 menunjukan SLI kurang mampu menyatakan ulang konsep segiempat. Hal tersebut dikarenakan SLI kurang teliti sehingga salah dalam memilih bangun persegipanjang dan penjelasan dari SLI kurang jelas.

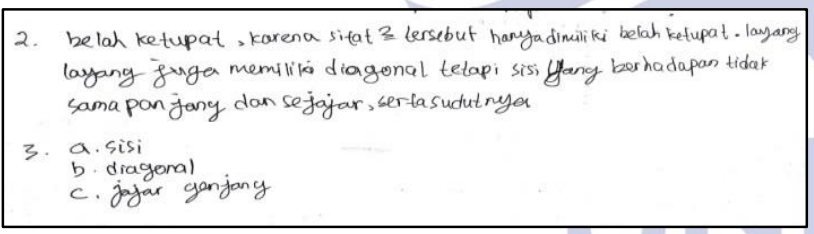

Gambar 14. SLI Mengklasifikasikan Segiempat

Berdasarkan Sifat-Sifat Yang Sesuai

Gambar 14 menunjukan SLI salah dalam menentukan suatu bangun segiempat berdasarkan sifat-sifat yang tertera dengan mengira bahwa sifat-sifat yang ada merupakan sifat-sifat yang dimiliki belahketupat. Namun pada soal selanjutnya SLI menjawab dengan benar bagianbagian pada bangun dan suatu bangun berdasarkan gambar yang ada. Dapat dikatakan SLI kurang mampu mengklasifikasikan segiempat berdasarkan sifat-sifat yang sesuai

4. Segitiga, lingaran, segilima karena lidakmeniliki 4 sisi
5. belah ketupat, layang-layany, jajar gen jang

Gambar 15. SLI dalam Memberikan Contoh dan NonContoh Dari Segiempat
Gambar 15 menunjukan SLI dapat memberikan contoh dan non-contoh dari segiempat. Hal ini dikarenakan subjek SLI dapat memberikan non-contoh dengan benar beserta penjelasan dari non-contoh yang diberikan sudah benar. SLI juga dapat memberikan contoh dari segiempat dengan benar, akan tetapi SLI kurang dalam memberikan contoh dari segiempat. Tetapi saat wawancara, SLE terlihat mampu memberikan contoh dari segiempat dengan tepat. Berikut transkrip wawancara SLI dalam memberikan contoh dan non-contoh dari segiempat

\begin{tabular}{|l|c|l|}
\hline P4071 & $:$ & $\begin{array}{l}\text { Coba kamu sebutkan bangun datar yang } \\
\text { bukan termasuk segiempat dan apa } \\
\text { alasanya? }\end{array}$ \\
\hline SLI4071 & $:$ & $\begin{array}{l}\text { Segtiga, lingkaran, segilima. Karena tidak } \\
\text { memiliki 4 sisi }\end{array}$ \\
\hline P5072 & $:$ & $\begin{array}{l}\text { Selanjutnya coba kamu sebutkan empat } \\
\text { contoh segiempat }\end{array}$ \\
\hline SLI5072 & $:$ & Belahketupat, jajargenjang dan persegi \\
\hline P5073 & $:$ & $\begin{array}{l}\text { Tetapi mengapa jawabanmu disini hanya } \\
\text { menyebutkan 3, coba sebutkan lagi contoh } \\
\text { dari segiempat? }\end{array}$ \\
\hline SLI5073 & $:$ & Ohh iya kak. layang-layang \\
\hline
\end{tabular}

Gambar 16. transkrip wawancara SLI dalam memberikan contoh dan non-contoh dari segiempat

Gambar 16 menunjukan SLI dapat menyebutkan noncontoh berserta penjelasanya, selain itu SLI mampu menyebutkan contoh-contoh dari segiempat dengan benar

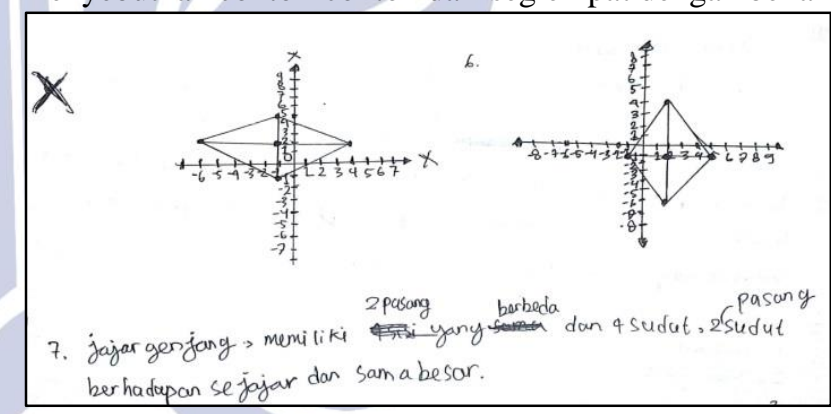

Gambar 17. SLI dalam Menyajikan Konsep Segiempat

dalam Berbagai Bentuk Repsresentasi Matematika

Gambar 17 menunjukan SLI mampu menyajikan informasi verbal ke dalam bentuk visual dengan benar, namun belum menuliskan dimana titik E berada dan belum menyebutkan bangun yang terbentuk. Selanjutnya SLI juga mampu mengubah informasi visual ke dalam bentuk verbal hanya saja terdapat kata yang kurang jelas, ketika wawancara SLI mampu menjelaskan dimana titik E berada, mampu menyebutkan bangun yang terbentuk dan mampu menjelaskan secara verbal dengan baik. Berikut transkrip wawancara SLI dalam menyajikan konsep segiempat ke dalam berbagai bentuk representasi matematika 


\begin{tabular}{|l|c|l|}
\hline P6074 & $:$ & $\begin{array}{l}\text { Coba pada soal ini bangun apa yang } \\
\text { terbentuk? Dan jelaskan cara kerjamu! }\end{array}$ \\
\hline SLI6074 & $:$ & $\begin{array}{l}\text { Belahketupat kak, awalnya saya membuat } \\
\text { sumbu koordinat terlebih dahulu dan } \\
\text { menepatkan titik-titik sesuai informasi kak, } \\
\text { sebenarnya saya awalnya kebingungan } \\
\text { (x,y)nya kak, terus saya hubungkan titik-titik } \\
\text { itudan jadinya bentuk belahketupat kak }\end{array}$ \\
\hline P6075 & $:$ & Bagaimana dengan koordinat titik E? \\
\hline SPE6075 & $:$ & Koordinat titik E itu tertelak di (2,-1) kak \\
\hline P7076 & $:$ & $\begin{array}{l}\text { Termasuk bangun apakah ini? Coba jelaskan } \\
\text { informasi apa saja yang kamu dapatkan? }\end{array}$ \\
\hline SPE7076 & $:$ & $\begin{array}{l}\text { Telihat dari gambar ini merupakan } \\
\text { jajargenjang, memiliki 2 pasang sisi yang } \\
\text { berhadapan sama, memiliki 4 sudut, dan } \\
\text { memiliki 2 diagonal }\end{array}$ \\
\hline
\end{tabular}

Gambar 18. Transkrip wawancara SLI dalam menyajikan konsep segiempat ke dalam berbagai bentuk representasi matematika

Gambar 18 menunjukan SLI awalnya mengalami kebingungan dalam mengubah informasi verbal ke dalam bentuk visual, pada akhirnya SLI mampu menggambarkan secara visual dengan benar dan menyebutkan bangun yang terbentuk dan menjelaskan pengerjaan dengan jelas, serta mampu menyebutkan letak titik E berada. Selain itu SLE mampu menjabarkan informasi secara verbal dengan jelas dan benar, oleh karena itu SLE mampu menyajikan konsep segiempat ke dalam berbagai bentuk representasi matematika dengan baik.

\begin{tabular}{|c|c|c|}
\hline 3. $\begin{aligned} L \square & =P \times L \\
& =12 \times 6 \\
& =72 \mathrm{~cm}^{2}\end{aligned}$ & $\begin{aligned} \angle D & =S^{2} \\
& =6^{2} \\
& =36 \mathrm{~cm}^{2}\end{aligned}$ & $\begin{array}{l}L \square+\angle \square]=7.2 \mathrm{~cm}^{2}+36 \mathrm{~cm}^{2} \\
=108 \mathrm{~cm} \\
k=6+6+6+6+12+12 \\
=48 \mathrm{~cm}\end{array}$ \\
\hline
\end{tabular}

Gambar 19. SLI dalam Menggunakan dan Memanfaatkan Serta Memilih Prosedur atau Operasi Untuk

\section{Menyelesaikan Soal Segiempat}

Gambar 19 menunjukan SLI mampu menggunakan dan memanfaatkan serta memilih prosedur atau operasi untuk menyelesaikan soal segiempat dengan. Hal ini terlihat SLI menggunakan strategi bagus untuk menentukan luas pada bangun tersebut dengan membagi menjadi 2 bangun dan SLI mampu menjawab dengan benar dalam menetukan luas bangun, kemudian dalam menentukan keliling SLI mampu menjawab dengan benar.

\section{d. Subjek Perempuan Berkepribadian Introvert (SPI)}

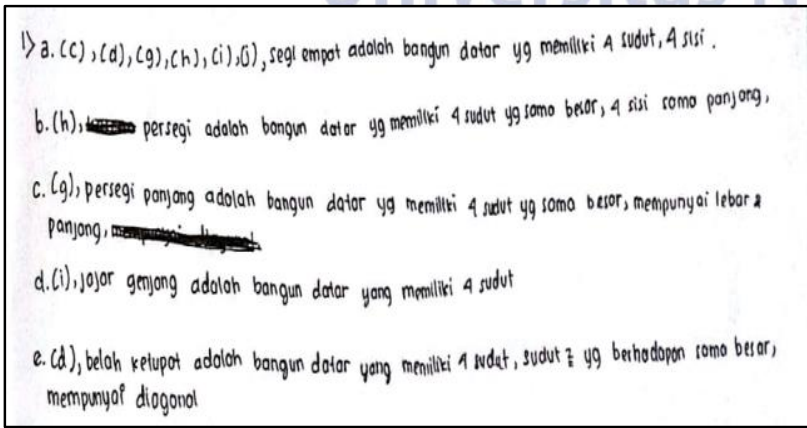

Gambar 20. SPI dalam Menyatakan Ulang Konsep Segiempat

Gambar 20 menunjukan SPI dalam menyatakan ulang konsep sudah baik. Hal ini terlihat subjek SPI menggolongkan bangun segiempat dengan benar, dan menentukan persegi, persegipanjang, belahketupat, jajargenjang dengan benar serta memberikan deskripsi tiap bangun yang ditanyakan dengan baik hanya saja pada bagian jajargenjang harus ditelusuri melalui wawancara untuk mencari kejelasan. Berikut transkrip wawancara SPI dalam menyatakan ulang konsep segiempat pada bagian jajargenjang

\begin{tabular}{|c|c|c|}
\hline P1d088 & $:$ & $\begin{array}{c}\text { Baiklah, selanjutnya mana yang termasuk } \\
\text { jajargenjang dan apa yang kamu ketahui dari } \\
\text { jajargenjang? }\end{array}$ \\
\hline SPI1d088 & $:$ & Yang (I) kak, Jajargenjang yaitu bangun datar \\
& & yang memiliki 4 sudut \\
\hline P1d089 & $:$ & Selain itu, apakah hanya itu yag kamu ketahui? \\
\hline SPI1d089 & $:$ & Oh, memiliki dua pasang sisi sejajar kak \\
\hline
\end{tabular}

Gambar 21. Transkrips wawancara SPI dalam menyatakan konsep segiempat

Gambar 21 terlihat SPI mampu menjelaskan jajar genjang dengan baik. Dengan begitu dapat dikatakan bahwa SPI mampu menyatakan ualang konsep segiempat dengan baik.

2) belah retupat, karena belah retupat memiliki sleat? tersebut,
3)a. sisi alas
b.garis diagonal
c.jajor genjang, karena

Gambar 22. SPI dalam Mengklasifikasikan Segiempat Berdasarkan Sifat-Sifat Yang Sesuai

Gambar 22 menunjukan SPI dalam mengklasifikasikan segiempat berdasarkan sifat-sifat yang sesuai masih kurang. Terlihat subjek SLI salah dalam menentukan suatu bangun segiempat berdasarkan sifat-sifat yang tertera dengan mengira bahwa sifat-sifat yang ada merupakan sifat-sifat yang dimiliki belahketupat. Namun pada soal selanjutnya subjek SPI mampu menyebutkan bagian pada bangun dan mampu menyebutkan bangun yang dimaksud dengan benar serta memberikan penjelasan yang baik hanya saja subjek SPI tidak menulisakan penjelasan pada lembar jawaban.

\section{4) Segitiga, lingkaran, segikımal seglenam \\ 5) Trapesium, belah ketupots jajor genjong, layang-layang}

Gambar 23. SPI dalam Memberikan Contoh dan NonContoh Dari Segiempat

Gambar 23 terlihat SPI dapat memberikan contoh dari segiempat dan non-contoh dari segiempat dengan benar hanya saja subjek SPI belum menuliskan alasan terkait non-contoh pada lembar jawaban. Tetapi setelah dilakukan wawancara, SPI mampu menjelaskan alasannya dengan jelas. Berikut transkrip wawancara SPI dalam memberikan contoh dan non-contoh dari segiempat 


\begin{tabular}{|l|c|l|}
\hline P4096 & $:$ & $\begin{array}{l}\text { Coba kamu sebutkan bangun datar yang bukan } \\
\text { termasuk segiempat dan apa alasanya? }\end{array}$ \\
\hline SPI4096 & $:$ & $\begin{array}{l}\text { Segtiga, lingkaran, segilima, segienam. Karena } \\
\text { sisinya tidak berjumlah 4 }\end{array}$ \\
\hline P5097 & $:$ & $\begin{array}{l}\text { Selanjutnya coba kamu sebutkan empat contoh } \\
\text { segiempat }\end{array}$ \\
\hline SPI5097 & $:$ & $\begin{array}{l}\text { Trapesium, belahketupat, layang-layang, } \\
\text { jajargenjang }\end{array}$ \\
\hline
\end{tabular}

Gambar 24. Transkrip wawancara SPI dalam memberikan contoh dan non-contoh dari segiempat

Gambar 24 menunjukan SPI mampu menyebutkan contoh dari segiempat dengan tepat, dan mampu memberikan non-contoh dari segiempat dengan benar serta memberikan alsan yang jelas.

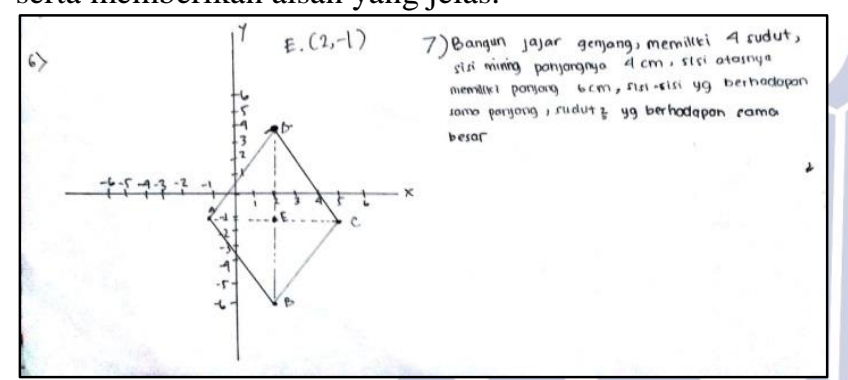

Gambar 25. SPI dalam Menyajikan Konsep dalam

Berbagai Bentuk Repsresentasi Matematika

Gambar 21 menunjukan SPI mampu menyajikan konsep dalam berbagai bentuk repsresentasi matematika. Hal ini terlihat subjek SPI mampu mengubah informasi verbal pada soal ke dalam bentuk visual dengan benar dan menyebutkan bangun yang terbentuk dengan tepat, serta dapat menentukan titik E. kemudian pada soal selanjutnya subjek SPI mampu menjawabarkan informasi secara verval dengan sangat lengkap.

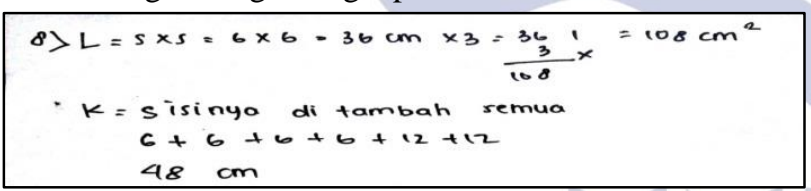

Gambar 26. SPI dalam Menggunakan dan Memanfaatkan

Serta Memilih Prosedur atau Operasi Untuk

Menyelesaikan Soal Segiempat

Gambar 26 menunjukan SPI mampu menggunakan dan memanfaatkan serta memilih prosedur atau operasi untuk menyelesaikan soal segiempat. Hal ini terlihat dari strategi yang digunakan SPI untuk menentukan luas bangun dengan membagi bangun pada soal menjadi tiga bangun persegi, SPI juga menjawab keliling dari bangun tersebut dengan benar dengan melakukan operasi dengan tepat.

2. Pembahasan

a. Subjek Laki-Laki Berkepribadian Ekstrovert (SLE)

Berdasarkan analisis hasil penelitian terkait pemahaman konsep segiempat untuk subjek laki-laki berkepribadian ekstrovert (SLE), terlihat SLE SLE kurang teliti dalam menggolongkan persegi dan penjelasan dari
SLE kurang jelas sehingga dalam menyatakan ulang konsep segiempat SLE masih kurang. Hal ini sesuai dengan Krutestski (dalam Amir 2013) yang mengatakan bahwa laki-laki tergolong kurang dalam ketepatan, ketelitian, keseksamaan berpikir, dan kecermatan, selanjutnya dalam penelitian Syamsiyah, (2018) yang menunjukan bahwa siswa laki-laki melakukan kesalahan dengan kurang teliti dalam membaca soal sehingga belum memenuhi tahap indikator menyatakan ulang konsep, selain itu Jung (dalam Djaali, 2008) mengatakan bahwa seseorang yang berkepribadian ekstrovert dalam menghadapi masalah/pekerjaan cenderung tidak sabar. Selanjutnya SLE kurang mampu menggunakan dan memanfaatkan serta memilih prosedur atau operasi untuk menyelesaikan soal segiempat dengan baik, dikarenakan SLE mengalami kesalahan serta kurang teliti dalam menyelesaikan soal, hal ini sesuai dengan penelitian Qomariah (2016), yang menyatakan siswa dengan kepribadian ekstrovert dalam menghadapi masalah cenderung kurang teliti dan tergesa-gesa. Selanjutnya, SLE mampu mengkalsifikasikan segiempat berdasarkan sifat-sifat yang sesuai dengan baik, mampu memberikan contoh dan non-contoh, dan mampu menyajikan konsep segiempat ke dalam berbagai bentuk repsresentasi matematika dengan baik.

b. Subjek Perempuan Berkepribadian Ekstrovert (SPE) Berdasarkan analisis hasil penelitian terkait pemahaman konsep segiempat untuk subjek perempuan berkepribadian ekstrovert (SPE), terihat SLI masih kurang dalam, hal ini dikarenakan SPE terburu-buru dan kurang teliti dalam melihat informasi dengan baik, Hal ini sesuai dengan pendapat itu Jung (dalam Djaali, 2008) mengatakan bahwa seseorang yang berkepribadian ekstrovert dalam menghadapi masalah/pekerjaan cenderung tidak sabar. Kemudian SPE belum mampu mengklasifikasikan segiempat berdasarkan sifat-sifat yang sesuai dikarenakan kurang cermat dalam membaca informasi yang ada untuk menentukan suatu segiempat berdasarkan sifat-sifat yang tertera. Hal ini sesuai dengan penelitian Pujiati, dkk (2018) yang menunjukan bahwa siswa dalam mengklasifikasikan objek-objek masih kurang hanya 39\%. Selanjutnya SPE belum bisa menggunakan dan memanfaatkan serta memilih prosedur atau operasi untuk menyelesaikan soal segiempat dengan baik dikarenakan SPE kurang teliti sehingga mengalami kesalahan dalam menentukan keliling. Hal ini sesuai dengan penelitian Qomariah (2016), yang menyatakan siswa dengan kepribadian ekstrovert kurang teliti dalam memahami informasi dan cenderung tergesa-gesa dalam menghadapi masalah. Selanjutnya SPE dapat memberikan contoh dan non-contoh dengan benar, dan juga dapat 
menyajikan konsep segiempat dalam berbagai bentuk repsresentasi matematika.

\section{c. Subjek Laki-Laki Berkepribadian Introvert (SLI)}

Berdasarkan analisis hasil penelitian terkait pemahaman konsep segiempat untuk subjek laki-laki berkepribadian introvert (SLI), terlihat SLI dalam menyatakan ulang konsep segiempat masih kurang dikarenakan SLI kurang teliti sehingga kurang tepat dalam memilih bangun persegi panjang. Hal ini sesuai dengan Krutestski (dalam Amir 2013) yang mengatakan bahwa laki-laki tergolong kurang dalam ketepatan, ketelitian, keseksamaan berpikir, dan kecermatan, selanjutnya hal ini didukung oleh penelitian Syamsiyah, Mamik (2018) yang menunjukan bahwa siswa laki-laki melakukan kesalahan dengan kurang teliti dalam membaca soal sehingga belum memenuhi tahap indikator menyatakan ulang konsep dan penjelasan dari subjek SLI kurang jelas. Kemudian SLI belum mampu mengklasifikasikan segiempat berdasarkan sifat-sifat yang sesuai dikarenakan kurang cermat dalam membaca informasi yang ada untuk menentukan suatu segiempat berdasarkan sifat-sifat yang tertera. Hal ini sesuai dengan penelitian Pujiati, dkk (2018) yang menunjukan bahwa siswa dalam mengklasifikasikan objek-objek masih kurang hanya 39\% Selanjutnya SLI mampu menyatakan ulang konsep segiempat dengan baik, mampu memberikan contoh dan non-contoh dari segiempat, mampu menyajikan konsep segiempat dalam berbagai bentuk repsresentasi matematika, mampu menggunakan dan memanfaatkan serta memilih prosedur atau operasi tertentu dengan baik. Hal ini sesuai dengan Qomariah (2016) yang menyatakan siswa dengan kepribadian introvert teliti dalam memahami informasi dalam menghadapi masalah.

\section{d. Subjek Perempuan Berkepribadian Introvert (SPI)}

Berdasarkan analisis hasil penelitian terkait pemahaman konsep segiempat untuk subjek perempuan berkepribadian introvert (SPI), terlihat SPI dalam mengklasifikasikan segiempat berdasarkan sifat-sifat yang sesuai masih kurang dikarenakan karena kurang cermat dalam membaca informasi yang ada untuk menentukan suatu segiempat berdasarkan sifat-sifat yang tertera. Hal ini sesuai dengan penelitian Pujiati, dkk (2018) yang menunjukan bahwa siswa dalam mengklasifikasikan objek-objek masih kurang hanya 39\%. Selanjutnya SPI mampu menyatakan ulang konsep segiempat dengan baik, memberikan contoh dan non-contoh dari segiempat dengan tepat, mampu menyajikan konsep segiempat dalam berbagai bentuk repsresentasi matematika, mampu menggunakan dan memanfaatkan serta memilih prosedur atau operasi untuk menyelesaikan soal segiempat dengan benar. Hal ini sesuai dengan Qomariah (2016) yang menyatakan siswa dengan kepribadian introvert teliti dalam memahami informasi dalam menghadapi masalah.

\section{PENUTUP}

\section{Simpulan}

a. Pemahaman konsep segiempat pada siswa laki-laki berkepribadian ekstrovert. Terlihat siswa laki-laki ekstrovert dapat mengklasifikasi segiempat berdasarkan sifat-sifat yang sesuai, dapat memberikan contoh dan non-contoh dari segiempat, dapat menyajikan konsep segiempat ke dalam berbagai bentuk representasi matematika dengan baik. Akan tetapi siswa laki-laki ekstrovert dalam menyatakan ulang konsep segiempat masih kurang, kemudian kurang tepat dalam menggunakan dan memanfaatkan serta memilih prosedur atau operasi untuk menyelesaikan soal segiempat.

b. Pemahaman konsep segiempat pada siswa perempuan berkepribadian ekstrovert. Terlihat siswa perempuan ekstrovert mampu memberikan contoh dan noncontoh dari segiempat dengan benar, mampu menyajikan konsep segiempat ke dalam berbagai bentuk representasi matematika dengan baik. Akan tetapi/siswa perempuan ekstrovert kurang mampu menyatakan ulang konsep segiempat dengan tepat, kurang mampu mengklasifikasikan segiempat berdasarkan sifat yang sesuai, kemudian kurang tepat dalam menggunakan dan memanfaatkan serta memilih prosedur atau operasi untuk menyelesaikan soal segiempat.

c. Pemahaman konsep segiempat pada siswa laki-laki berkepribadian introvert. Terlihat siswa laki-laki introvert mampu menyatakan ulang konsep segiempat, mampu memberikan contoh dan noncontoh dari segiempat, tepat dalam menggunakan dan memanfaatkan serta memilih prosedur atau operasi untuk menyelesaikan soal segiempat. Akan tetapi siswa laki-laki introvert kurang mampu mengklasifikasikan segiempat berdasarkan sifat yang sesuai dan kurang mampu menyajikan konsep segiempat ke dalam berbagai bentuk representasi matematika.

d. Pemahaman konsep segiempat pada siswa perempuan introvert. Terlilhat siswa perempuan introvert mampu menyatakan ulang konsep segiempat, mampu memberikan contoh dan non-contoh dari segiempat, mampu menyajikan konsep segiempat ke dalam berbagai bentuk representasi matematika, tepat dalam menggunakan dan memanfaatkan serta memilih prosedur atau operasi untuk menyelesaikan soal segiempat. Akan tetapi siswa perempuan introvert belum mampu mengklasifikasi segiempat berdasarkan sifat-sifat yang sesuai 


\section{Saran}

Peneliti mengemukakan beberapa saran berdasarkan penelitian yang telah dilakukan sebagai berikut.

1. Bagi para guru sebaiknya dapat memperhatikan berbagai kepribadian dari siswa baik laki-laki maupun perempuan, dengan demikian guru dapat mengetahui nama siswa yang membutuhkan bantuan khusus dan bahkan guru bisa menerapkan model pembelajaran yang tepat dan sesuai dengan kepribadian siswa baik laki-laki maupun perempuan. Sehingga siswa dapat memahami suatu materi dengan mudah dan cepat.

2. Untuk peneliti lain yang hendak melakukan penelitian yang relevan dengan penelitian ini, diharapkan untuk melakukan wawancara lebih mendalam guna memperluas hasil-hasil dan mendapatkan informasi lebi mengenai pemahaman siswa jika dilihat dari kepribadian yang dimiliki, baik laki-laki maupun perempuan.

3. Diharapkan ada kajian lebih lanjut dikarenakan keterbatasan penelitian ini, misalnya tentang pemahaman konsep siswa yang ditinjau dari pemahaman konsep dan jenis kelamin dengan materi yang berbeda

\section{DAFTAR PUSTAKA}

Amir, Zibaidah. 2013. "Perspektif gender dalam pembelajaran matematika". Marwah: Jurnal Perempuan, Agama Dan Jender, 12(1), 15-31.

Fatqurhohman. 2016. "Pemahaman Konsep Matematika Siswa Dalam Menyelesaikan Masalah Bangun Datar". dalam Jurnal Ilmiah Pendidikan Matematika, Vol. 4 No. 2, hlm 127-133.

Hamzah, B. Uno dan Masri, K Umar. 2009. Mengelola Kecerdasan dalam Pembelajaran. Jakarta: Bumi Aksara.

Jung.C.G. 2016. Psychological Types (Online), (http://www.cyjack.com/cognition/(ebook\%20pdf)\%2 0jung,\%20carl\%20-

\%20the\%20psychological\%20types.pdf, diakses 16 oktober 2019)

Kartono, Kartini. 2006. "Psikologi Wanita : Mengenal Gadis Remaja dan Wanita Dewasa". Bandung : Mandar Maju

Kiswanto, K. 2015. "Deskripsi Pemahaman Konsep Materi Geometri Ditinjau dari Kepribadian Sensing dan Intuition pada Siswa Kelas IX SMP Negeri 33 Makassar". Doctoral dissertation. Makassar: Universitas Islam Negeri Alauddin Makassar.
Lestari, Nurcholif. 2010. "Profil Pemecahan Masalah Matematika Open-Ended Siswa Kelas V Sekolah Dasar Ditinjau Dari Perbedaan Gender dan Kemampuan Matematka". Tesis tidak diterbitkan. Surabaya: Program Pascasarjana Universitas Negeri Surabaya.

Lutfiyah, S. M., dkk. 2018. "Profil Pemahaman Konsep Siswa Laki-laki dalam pemecahaman Masalah Matematika Menurut Tahapan Polya”. Makalah disajikan pada Seminar Nasional Matematika dan Pendidikan Matematika (3th SENATIK). Semarang: Universitas PGRI Semarang.

Noureen, G \& Sheikh, I. 2016. "Students mathematical problem-solving proficiency in relation to gender at grade VI. Journal of Research and Reflection in Education, 10(2), 123-131.

Nuryoto, S. 1998. "Perbedaan prestasi akademik antara laki-laki dan perempuan studi di wilayah Yogyakarta". Jurnal Psikologi, No 2, 16-24.

OECD. 2014. PISA Results: Creative Problem Solving: Students' Skills in Tackling Real-Life Problems. (Online). (http://www.oecd.org/pisa/keyfindings/pisa2012-results-volume-v.htm/, diakses pada 16 oktober 2019).

Pangarso, Astadi. 2012. Prilaku Organisasi. (online) http://www.slideshare.net/a57adee/2-kepribadian, diakses pada 10 Desemberr 2019).

Pujiati, P., Kanzunnudin, M., \& Wanabuliandari, S. 2018. "Analisis Pemahaman Konsep Matematis Siswa Kelas IV SDN 3 Gemulung Pada Materi Pecahan". ANARGYA: Jurnal Ilmiah Pendidikan Matematika, 1(1), 37-41.

Qomariah, N. 2016. "Profil pemahaman siswa sma dalam memecahkan masalah persamaan kuadrat ditinjau dari perbedaan kepribadian extrovert dan introvert". Apotema: Jurnal Program Studi Pendidikan Matematika, 2(1), 87-85.

Sunardi, S. 2009. Hubungan Tingkat Berpikir Siswa dalam Geometri dengan Kemampuan Siswa dalam Geometri. Matematika, 6(2).

Syamsiyah, M. 2018. "Pemahaman Konsep Teorema Phytagoras Pada Siswa Berkemampuan Matematika Tinggi Ditinjau Dari Perbedaan Gender".

Zulkardi. 2003. Pendidikan Matematika di Indonesia: Beberapa Permasalahan dan Upaya Penyelesaiannya. Palembang: Universitas Sriwijaya. 